\title{
PEMECAHAN MASALAH USAHA DAN ENERGI DENGAN MODEL PEMBELAJARAN BERBASIS PROYEK DITINJAU DARI KETERAMPILAN BERPIKIR KRITIS PESERTA DIDIK
}

\author{
Nurwahyuningsih*, Ahmad Harjono, Satutik Rahayu. \\ Program Studi Pendidikan Fisika, Universitas Mataram \\ Email: Nurwahyuningsih478@gmail.com
}

DOI: http://dx.doi.org/10.29303/jpft.v5i2.1325

\begin{abstract}
The research have three aimed that include :(1) examine the effect of guided project based learning toward problem solving, (2) examine the effect of guided critical thinking ability toward problem solving, and (3) examine the interaction between project based leraning and critical thinking ability toward problem solving. This research is quasi experiment with factorial $2 \times 2$ design. The population is all of class XI MIPA in SMAN 1 Narmada. The sampling tehnique is cluster random sampling which XI MIPA 3 as experiment group with project based learning model and XI MPA 2 as control group with convensional model. Tehnique of collecting data of problem solving using essay test 7 question and collecting data of critical thinking ability using essay test 5 question. Data of research is normal and homogen that showed by $F_{\text {quantification }}<F_{\text {tabel }}=1,27<1,78, \chi_{\text {quantification }}^{2} \chi_{\text {tabel }}^{2}=$ $9,17<11,07$ and 5,17<11,07. Data of reserach is analysed by anava two way with SPSS 18.0. The result of anava two way test showed that: (1) $\mathrm{sig}_{A}$ quantification $<0,05$ is $0,001<0,05$ which $\mathrm{H}_{0 \mathrm{~A}}$ rejected and $H_{I A}$ accepted, that showed there is the effect of project based learning toward problem solving. (2) $\operatorname{sig}_{B}$ quantification $<0,05$ is $0,001<0,05$ which $H_{O B}$ rejected and $H_{1 B}$ accepted, that showed there is the effect of critical thinking ability toward problem solving. (3) $\operatorname{sig}_{A B}$ quantification $>0,05$ is $0,69>0,05$ which $H_{O A B}$ accepted dan $H_{I A B}$ rejected, that showed there is not interaction between project based learning and critical thinking ability toward problem solving.
\end{abstract}

Keywords: Project based learning; problem solving; critical thinking ability.

\section{PENDAHULUAN}

Fisika adalah bagian dari ilmu pengetahuan alam (IPA) yang mempelajari gejala alam atau fenomena alam serta semua interaksi yang menyertainya. Fisika merupakan pengetahuan yang dapat mengembangkan daya nalar, analisis, sehingga hampir semua persoalan yang berkaitan dengan alam dapat dimengerti (Arini dan Juliadi, 2018). Pengetahuan tersebut diperoleh melalui pembelajaran, penguasaan pengetahuan, proses penemuan, konsep-konsep, dan fakta-fakta yang melingkupi kebenaran dari hukumhukum alam yang terjadi (Wulandari et al. 2017). Ilmu Pengetahuan Alam atau sains memiliki defenisi yang penting untuk dipahami. Sains didefinisikan sebagai ilmu yang mempelajari tentang sebab akbibat peristiwa-peristiwa yang terjadi di alam (Gunawan, 2015). Melalui sains, peserta didik belajar mengamati pola-pola hubungan dari subjek yang dipelajari dan berlatih menemukan hal yang menjadi sebab dan hal yang menjadi akibat (Gunawan, 2017)

Salah satu kendala yang dihadapi para guru fisika adalah kemampuan problem-solving yang bersifat parsial. Kondisi ini berdampak pada proses pembelajaran fisika yang kurang menarik karena guru tidak dapat menguraikan materi secara luas, serta secara deduktif tidak dapat memprediksi semua kemungkinan peristiwa yang dapat terjadi ketika mereka dihadapkan pada suatu persoalan fisika tertentu (Rokhmat, 2012).

Mutu pendidikan ditentukan oleh berbagai faktor, salah satu diantaranya adalah proses belajar mengajar (Sahidu et al. 2018). Hasil observasi yang dilakukan didapatkan bahwa pembelajaran fisika di dalam kelas cenderung mengesampingkan kemampuan pemecahan masalah. Pada saat menjawab soal-soal fisika peserta didik 
mengalami kesulitan. Peserta didik mampu untuk menjelaskan dan menyelesaikan permasalahan kuantitatif sederhana namun kurang memiliki kemampuan untuk menjelaskan masalah yang lebih rumit. Menuliskan apa yang diketahui, ditanya dan menggunakan rumus serta melakukan perhitungan seringkali kalinya terdapat kekeliruan. Kurang pemahaman terhadap konsep ilmu fisika yang dipelajari juga menyulitkan mereka dalam menyelesaikan permasalahan fisika karena tidak dapat menerapkan konsep yang dipelajari secara benar dan tepat.

Pada aktivitas pembelajaran fisika lebih banyak menggunakan metode presentasi. Metode ini cukup baik dalam memfasilitasi proses pembelajaran. Kelemahan dari metode ini bahwa peserta didik tidak mampu memahami apa yang dipresentasikan penyaji dengan baik dan tidak semua peserta didik mampu berdiskusi setelah presentasi disampaikan. Kegiatan praktikum terhadap fisika juga jarang dilakukan. Hal ini dikarenakan alat-alat di laboratorium tidak begitu lengkap. Situasi pembelajaran seperti ini menyebabkan peserta didik tidak mampu memahami fisika dengan baik sehingga tidak mampu memecahkan masalah secara efektif.

Kemampuan memecahkan masalah sangat dibutuhkan oleh peserta didik, karena pada dasarnya peserta didik dituntut untuk berusaha sendiri mencari pemecahan masalah serta pengetahuan yang menyertainya, menghasilkan pengetahuan yang benar-benar bermakna (Hertiavi et al. 2010). kemampuan pemecahan masalah merupakan kemampuan yang sangat penting yang perlu dikembangkan dalam pembelajaran sains dimana merupakan kombinasi dari pemahaman seseorang untuk diterapkan dalam sebuah prosedur guna mencari jalan keluar terhadap sebuah permasalahan (Jannah et al. 2015).
Kemampuan pemecahan masalah bagi peserta didik perlu diupayakan agar peserta didik mampu mencari solusi berbagai permasalahan, baik pada bidang IPA maupun masalah dalam kehidupan sehari-hari yang semakin kompleks. Santrock (2007) menyatakan bahwa pemecahan masalah adalah mencari cara yang tepat untuk mencapai suatu tujuan. Contoh tugas-tugas yang mensyaratkan agar peserta didik melakukan upaya pemecahan masalah adalah membuat proyek untuk pekan raya sains atau menulis makalah. Dalam kegiatan belajar memecahkan masalah peserta didik terlibat dalam berbagai tugas, penentuan yang ingin dicapai dan kegiatan untuk melaksanakan tugas. Kemampuan pemecahan masalah bagi peserta didik perlu diupayakan agar peserta didik mampu mencari solusi berbagai permasalahan dalam kehidupan sehari-hari yang semakin kompleks (Ulya, 2015). Menurut Rohkmat (2015) kemampuan pemecahan masalah mengacu pada upaya yang diperlukan peserta didik dalam menentukan solusi atas masalah yang dihadapi.

Model pembelajaran merupakan cara yang digunakan untuk mengimplementasikan rencana yang sudah disusun dalam bentuk kegiatan nyata dan praktis untuk mencapai tujuan pembelajaran, sedangkan bahan ajar merupakan segala bahan baik tertulis maupun tidak tertulis yang digunakan untuk membantu siswa dalam belajar terutama saat proses pembelajaran berlangsung (Puryadi et al. 2018).

Model pembelajaran berbasis proyek adalah suatu pendekatan pendidikan yang efektif yang berfokus pada kreatifitas berfikir, pemecahan masalah, dan interaksi antara siswa dengan kawan sebaya mereka untuk menciptakan dan menggunakan pengetahuan baru. Melalui pembelajaran berbasis proyek, pebelajar akan bekerja di 
dalam tim, menemukan keterampilan merencanakan, mengorganisasi, bernegosiasi, dan membuat konsensus tentang isu-isu tugas yang akan dikerjakan, siapa yang bertanggungjawab untuk setiap tugas, dan bagaimana informasi akan dikumpulkan dan dipresentasikan secara ilmiah (Rais, 2010).

Pembelajaran berbasis proyek merupakan pembelajaran yang berpusat pada proses, relatif berjangka waktu, berfokus pada masalah, unit pembelajaran bermakna dengan memadukan konsepkonsep dari sejumlah komponen baik itu pengetahuan, disiplin ilmu atau lapangan. Pada pembelajaran berbasis proyek kegiatan pembelajarannya berlangsung kolaboratif dalam kelompok heterogen. Pembelajaran berbasis proyek memiliki potensi yang sangat besar untuk melatih proses berpikir mahasiswa yang mengarah pada keterampilan berpikir kritis mahasiswa. Keterampilan berpikir kritis dikembangkan di setiap tahapan pembelajaran berbasis proyek. Mahasiswa menjadi terdorong di dalam belajar mereka, dosen berperan sebagai mediator dan fasilitator (Sutrio et al. 2018). Adapun tahapan pembelajarannya menurut Trianto (2013) adalah memulai dengan pertanyaan dasar, merencanakan proyek, membuat jadwal, memonitoring, menguji hasil dan mengevaluasi proyek yang dikerjakan peserta didik.

Berdasarkan beberapa pendapat di atas dapat disimpulkan bahwa pembelajaran berbasis proyek adalah suatu model pembelajaran yang memfokuskan belajar secara mandiri dalam suatu kerja proyek untuk membagun pengetahuan. Fokus pembelajaran melibatkan peserta didik dalam pemecahan masalah melalui kerja proyek, memberi kesempatan peserta didik bekerja secara otonom mengkonstruk pengetahuan mereka sendiri, dan mencapai puncaknya menghasilkan produk pada akhir proses pembelajaran.

Salah satu faktor penting yang mempengaruhi keberhasilan peserta didik dalam memecahkan masalah dengan menggunakan model pembelajaran berbasis proyek adalah keterampilan berpikir kritis. Berpikir kritis adalah pemikiran reflectif dan produktif, dan melibatkan evaluasi bukti (Santrock, 2007). Menurut Ennis (2011) Ia berpendapat bahwa critical thinking is reasonable and reflective thinking focused on deciding what to believe or do. Definisi ini menjelaskan berpikir kritis menekankan pada berpikir yang masuk akal dan reflektif. Berpikir yang masuk akal dan reflektif ini digunakan untuk mengambil keputusan. Fisher (2007) menyatakan keterampilan berpikir kritis adalah keterampilan yang bernilai dan akan membantu dalam banyak hal.

Berdasarkan pendapat diatas dapat disimpulkan berpikir kritis adalah kemampuan yang dimiliki oleh individu untuk mengembangkan pengetahuan yang dimiliki, mengevaluasi, dan menghubungkan dengan fakta atau informasi dari berbagai sumber untuk memecahkan masalah. Keterampilan berpikir kritis lebih mungkin untuk tumbuh dan berkembang dalam lingkungan yang selalu adanya rasa ingin tahu dalam sebuah proses untuk memecahkan masalah. Adanya keterampilan berpikir kritis akan memberikan kemudahan bagi peserta didik dalam memecahkan masalah karena akan mampu menganalisa berbagai cara dan perspektif dalam memecahkan masalah.

\section{METODE PENELITIAN}

Penelitian kuasi eksperimen ini menggunakan design faktorial $2 \times 2$. Suatu penelitian memiliki beberapa variabel penelitian sehingga pembaca mengetahui alur dari sebuah eksperimen. Penelitian ini melibatkan variabel bebas yaitu model 
pembelajaran berbasis proyek atau dikenal juga sebagai project based learning (PJBL), variabel terikat yaitu kemampuan pemecahan masalah usaha dan energi, dan variabel moderator yaitu keterampilan berpikir kritis.

Populasi seluruh peserta didik kelas X MIPA yang berjumlah 107 orang. Tehnik pengambilan sampel menggunakan cluster random sampling sehingga diperoleh $\mathrm{X}$ MIPA 3 sebagai kelas eksperimen dan $\mathrm{X}$ MIPA 2 sebagai kelas kontrol.

Data hasil berpikir kritis dan pemecahan masalah diperoleh melalui instrumen tes uraian dengan jumlah 7 soal pemecahan masalah Pemahaman (understanding) yaitu kemampuan memahami ide atau gagasan dalam setiap soal; (2) Pemilihan (selecting) yaitu kemampuan memilih dan/atau penyebabpenyebab dan memprediksi kemungkinan akibat yang dapat terjadi; (3) Pembedaan (differentiating) yaitu kemampuan membedakan dan memilih penyebabpenyebab yang dapat menghasilkan suatu akibat tertentu; (4) Penentuan (determining) yaitu kemampuan menentukan konsep, prinsip, teori, dan/atau hukum fisika yang dapat digunakan untuk mendukung dalam mengidentifikasi sebuah atau beberapa penyebab sehingga menghasilkan suatu akibat; (5) Penerapan (applying) yaitu kemampuan menggunakan konsep, prinsip, teori, dan/atau hukum fisika dalam mengidentifikasi penyebab penyebab sehingga menghasilkan suatu akibat tertentu; (6) Pengidentifikasian (identifying) yaitu kemampuan mengidentifikasi kondisi penyebabpenyebab sehingga dapat menghasilkan suatu akibat tertentu (Rokhmat, 2015). Instrumen tes kemampuan pemecahan masalah sebelum digunakan harus memenuhi beberapa syarat yaitu uji validitas, reliabilitas, tingkat kesukaran soal dan daya beda. Sedangkan untuk soal berpikir kritis digunakan 5 soal ketermapilan beripikir kritis dengan indikator yaitu (1) klarifikasi dasar, (2) keterampilan dasar, (3) menyimpulkan, (4) memberikan penjelasan lanjut dan (5) menalar dan pengintegrasian (Ennis, 2011). Instrumen tes keterampilan berpikir kritis sebelum digunakan dilakukan uji validitas uji.

Uji hipotesis penelitian ini menggunakan uji anava dua arah dengan menggunakan bantuan SPSS 18 dengan kriteria jika Jika sig $_{\text {A hitung }} \leq 0,05$, maka $\mathrm{H}_{\mathrm{o}}$ ditolak $\mathrm{H}_{1}$ diterima, artinya ada pengaruh model pembelajaran berbasis proyek terhadap pemecahan masalah usaha dan energi. Jika $s i g_{\text {A hitung }}>0,05$, maka $\mathrm{H}_{\mathrm{o}}$ diterima $\mathrm{H}_{1}$ ditolak, artinya tidak ada pengaruh model pembelajaran berbasis proyek terhadap pemecahan masalah usaha dan energi (Siregar, 2013).

\section{HASIL DAN PEMBAHASAN}

Tujuan penelitian ini adalah pertama, untuk mengetahui pengaruh model pembelajaran berbasis proyek terhadap pemecahan masalah. Kedua, untuk mengetahui pengaruh keterampilan berpikir kritis terhadap pemecahan masalah. Ketiga, untuk mengetahui interaksi model pembelajaran berbasis proyek dengan keterampilan berpikir kritis terhadap pemecahan masalah. Data hasil penelitian yang diperoleh dianalisis menggunakan anava dua arah berbantuan SPSS.

Berikut hasil uji anava dua arah dengan menggunakan SPSS 18 diperoleh hasil seperti ditunjukkan pada Tabel 1 .

\section{Pemecahan Masalah Usaha Dan Energi Dengan Model Berbasis Proyek}

Hasil uji hipotesis penelitian menggunakan SPSS menunjukkan bahwa ada pengaruh model pembelajaran berbasis proyek terhadap pemecahan masalah usaha dan energi. Hal ini terlihat dari nilai 
signifikasi hitung yang lebih kecil dari signifikasi 0,05 . Faktor yang menyebabkan model pembelajaran berbasis proyek berpengaruh terhadap pemecahan masalah yaitu model pembelajaran ini menuntut partsispasi aktif peserta didik selama proses pembelajaran melalui kerja sama kelompok dalam menyelesaikan tugas proyek secara ilmiah. Selain itu, dalam pembelajaran berbasis proyek peserta didik dapat membangun pengetahuannya sendiri, motivasi belajarnya lebih tinggi, mendorong peserta didik untuk mengembangkan dan mempraktikkan keterampilan komunikasi, melibatkan peserta didik untuk belajar mengambil informasi dan menunjukkan pengetahuan yang dimiliki, kemudian diimplementasikan dengan dunia nyata dan membuat suasana belajar menjadi menyenangkan sehingga peserta didik menjadi lebih paham mengenai konsep usaha dan energi serta dapat menyelesaikan masalah usaha dan energi dengan lebih efektif.

Tabel 1. Hasil Analisis Hipotesis Menggunakan SPPS 18

Dependent Variable:PemecahanMasalah

\begin{tabular}{llllll}
\hline Source & $\begin{array}{l}\text { Type III Sum } \\
\text { of Squares }\end{array}$ & Df & Mean Square & F & Sig. \\
\hline Corrected Model & $8745,586^{\mathrm{a}}$ & 3 & 2915,195 & 21,138 &, 000 \\
Intercept & 308760,753 & 1 & 308760,753 & 2238,790 &, 000 \\
ModelPembelajaran & 5440,550 & 1 & 5440,550 & 39,449 &, 000 \\
$\begin{array}{l}\text { BerpikirKritis } \\
\text { ModelPembelajaran }\end{array}$ & 3683,624 & 1 & 3683,624 & 26,710 &, 000 \\
$*$ BerpikirKritis & 22,097 & 1 & 22,097 &, 160 &, 690 \\
Error & 9240,245 & 67 & 137,914 & & \\
Total & 338718,000 & 71 & & & \\
Corrected Total & 17985,831 & 70 & & & \\
\hline
\end{tabular}

Hal tersebut didukung oleh pendapat Rais (2010) menyatakan bahwa pembelajaran berbasis proyek adalah suatu pendekatan pendidikan yang efektif yang berfokus pada pemecahan masalah, kreatifitas berfikir, dan interaksi antara peserta didik dengan kawan sebaya mereka untuk menciptakan dan menggunakan pengetahuan baru. Melalui pembelajaran berbasis proyek, pebelajar akan bekerja di dalam tim, menemukan keterampilan merencanakan, mengorganisasi, bernegosiasi, dan membuat konsensus tentang isu-isu tugas yang akan dikerjakan, siapa yang bertanggungjawab untuk setiap tugas, dan bagaimana informasi akan dikumpulkan dan dipresentasikan secara ilmiah. Pendapat Halil (2008) menegaskan bahwa project based learning (PJBL) membantu penyelidikan yang mengarah pada pebelajar dalam menyelesaikan masalah-masalah nyata yang lebih luas, memberikan kesenangan dalam belajar, dan akan menjadi pembelajaran yang efektif dan strategis. Dan pendapat Trianto (2013) menyatakan bahwa model pembelajaran berbasis proyek merupakan pembelajaran yang berpusat pada peserta didik (student center) dan menempatkan guru sebagai motivator dan fasilitator, dimana peserta didik diberi peluang bekerja secara otonom mengkonstruksi belajarnya.

\section{Keterampilan Berpikir Kritis Terhadap Pemecahan Masalah Usaha dan Energi}

Berdasarkan hasil analisis menggunakan SPSS diperoleh bahwa ada pengaruh keterampilan berpikir kritis terhadap pemecahan masalah usaha dan energi. Hal ini terlihat dari nilai signifikasi hitung yang lebih kecil dari signifikasi 0,05. Keterampilan berpikir kritis memiliki peranan yang penting dalam memecahkan masalah. Adanya keterampilan berpikir 
kritis akan memberikan peserta didik kemudahan dalam memecahkan masalah karena konsep yang diperoleh akan dikelolah secara baik di dalam memori sehingga dapat berpengaruh positif dalam memecahkan masalah.

Hal ini didukung oleh pendapat Fisher (2007) menyatakan keterampilan berpikir kritis adalah keterampilan yang bernilai dan akan membantu dalam banyak hal. Salah satunya dalam memecahkan masalah. Meador dalam Misbah (2016) mengatakan keberhasilan proses pemecahan masalah sangat dipengaruhi oleh keterampilan berpikir kritis peserta didik. Adanya keterampilan berpikir kritis peserta didik dapat menyelesaikan masalah secara optimal karena akan memandang masalah dari berbagai persfektif. Cara pandang yang demikian akan memnugkinkan peserta didik untuk dapat memecahkan masalah dengan berbagai cara. Odzen \& Gultekin (2008) megemukakan kemampuan berpikir yang tinggi, akan memberikan keberhasilan memecahkan masalah yang lebih efektif.

Rata-rata nilai berpikir kritis kelas eksperimen dengan perlakuan PJBL lebih tinggi dibandingkan kelas kontrol dengan perlakuan model pembelajaran konvensional. Hal ini sesuai dengan hasil penelitian Sugiyarti et al. (2015) menyatakan bahwa keterampilan berpikir kritis merupakan kemampuan untuk menganalisis fakta, mencetuskan dan menata gagasan, mempertahankan pendapat, membuat perbandingan, menarik kesimpulan, mengevaluasi argumen dan memecahkan masalah. Peserta didik yang memiliki kemampuan berpikir tinggi dapat memecahkan masalah dengan kritis. Penelitian dilakukan oleh Sawitri et al. (2016) mengemukakan peserta didik yang memiliki keterampilan berpikir kritis tinggi mampu menyelesaikan tes pengetahuan dengan baik. Hal ini yang menyebabkan adanya perbedaan yang signifikan pada keterampilan berpikir kritis tinggi dan rendah.

Keterampilan berpikir kritis adalah salah satu indikator hasil belajar yang perlu dilatih. Keterampilan berpikir kritis tidak akan berkembang apabila tidak dilatih (Yeritia et al. 2017). Pada dasarnya keterampilan berpikir kritis dapat menjadi dasar seseorang untuk mencari tau lebih dalam terhadap sesuatu hal. Dalam penelitian ini keterampilan berpikir kritis diperlukan dalam mencari kelengkapan data dari hasil praktikum secara tepat, mengkomunikasikan hasil, menyusun laporan serta mengaitkan teori dengan hasil percobaan. Namun, perbedaan perlakuan antara kelas eksperimen dan kontrol sangat mempengaruhi berpikir kritis pada peserta didik sehingga akan berdampak juga pada pemecahan masalah.

\section{Interaksi Model Pembelajaran Berbasis Proyek Dengan Keterampilan Berpikir Kritis Terhadap Pemecahan Masalah}

Hasil uji hipotesis ketiga menggunakan SPSS diperoleh bahwa tidak ada interaksi antara model pembelajaran berbasis proyek dan keterampilan berpikir kritis terhadap pemecahan masalah usaha dan energi. Hal ini terlihat dari nilai signifikasi hitung yang lebih besar dari signifikasi 0,05 . Berdasarkan perhitungan dengan menggunakan SPSS, diperoleh interaksi antara model pembelajaran berbasis proyek terhadap pemecahan masalah usaha dan energi ditinjau dari ketearmpilan berpikir kritis peserta didik pada Gambar 1. Terlihat pada Gambar 1, interaksi model pembelajaran dengan keterampilan berpikir kritis terhadap pemecahan masalah. Kedua garis menunjukkan hubungan antara model pembelajaran yakni model pembelajaran berbasis proyek (PJBL) dan model pembelajaran konvensional dengan berpikir kritis pada kedua kelas yakni berpikir kritis 
tinggi dan berpikir kritis rendah. Keduanya tidak berpotongan di satu titik melainkan terpisah satu sama lain, artinya tidak ada hubungan atau interaksi antara model pembelajaran berbasis proyek dengan berpikir kritis terhadap pemecahan masalah peserta didik. Hal ini sejalan dengan pendapat Hair et al. (2010) yang menyatakan bahwa interaksi dapat terjadi apabila variabel-variabel bebas tidak membawa akibat-akibat secara terpisah dan sendirisendiri. Sebaliknya interaksi dapat pula tidak terjadi jika lebih dari satu variabel bebas membawa akibat-akibat terpisah yang signifikan.

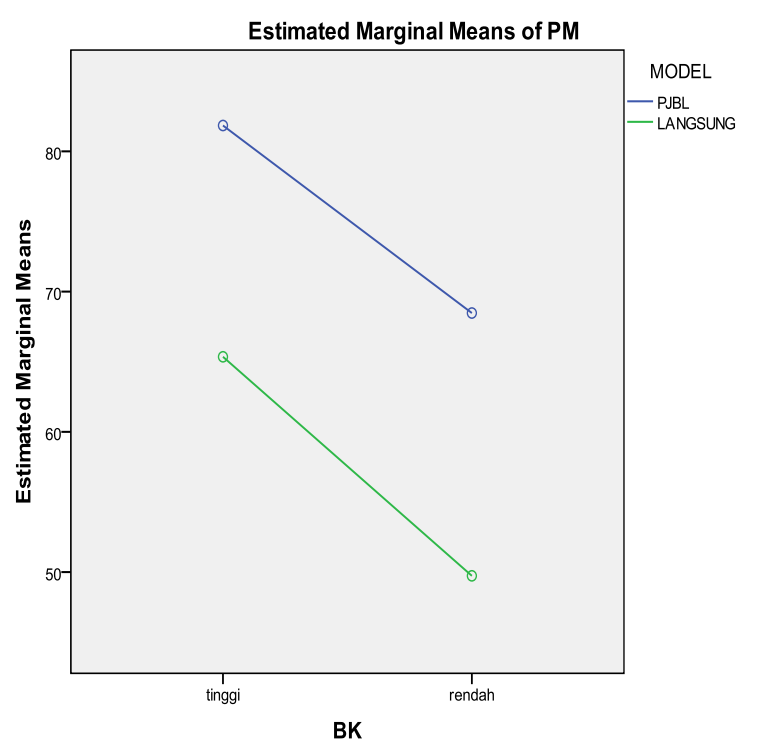

Gambar 1. Interaksi antara PJBL dengan berpikir kritis

\section{PENUTUP}

Berdasarkan data yang diperoleh dan hasil dari analisis data yang telah dikemukakan dapat disimpulkan beberapa hal, yaitu terdapat pengaruh model pembelajaran PJBL (Project based learning) terhadap pemecahan masalah usaha dan energi. Model pembelajaran PJBL memberikan pengaruh yang lebih baik dari pada model pembelajaran konvensional terhadap pemecahan masalah usaha dan energi. Kemampuan berpikir kritis pun turut mempengaruhi kemampuan pemecahan masalah usaha dan energi peserta didik.
Pemecahan masalah peserta didik yang memiliki kemampuan berpikir kritis tinggi akan memberikan pengaruh yang lebih baik dari pada peserta didik yang mempunyai kemampuan berpikir kritis yang rendah. Namun, model pembelajaran PJBL dengan kemampuan berpikir kritis tidak memiliki interaksi satu sama lain dalam mempengaruhi kemampuan pemecahan masalah peserta didik.

\section{REFERENSI}

Arini, W., \& Juliadi., F. 2018. Analisis Kemampuan Berpikir Kritis Pada Mata Pelajaran Fisika Untuk Pokok Bahasan Vektor Siswa Kelas X SMA Negeri 4 Libuklinggau Sumatera Selatan. Berkala fisika indonesia: STKIP PGRI Libuklingga, 10(1).

Ennis R H. 2011. The Nature of Critical Thinking: An Outline of Critical Thinking Dispositions and Abilities. University of Illinois. On line at http://faculty.education.illinois.edu /rhennis/documents/TheNatureofC riticalThinking_51711_000.pdf [diakses tanggal 1 Oktober 2016].

Fisher, A. 2009. Berpikir Kritis Sebuah Penghantar. Jakarta : Erlangga.

Gunawan. 2015. Model Pembelajaran Sains Berbasis ICT. Mataram: FKIP Universitas Mataram.

Gunawan. 2017. Keterampilan Berpikir dalam Pembelajaran Sains. Mataram: Arga Puji Press.

Hair, J.F., Black, W.C., Babi, B.J., \& Anderson, R.E. 2010. Multivariate Data Analysis a Globl Perspektive (7th ed.). Upper Saddle River : Pearson Education Inc.

Halil, T. 2008. Perspective Of Science Teachers Conceptualizations About Project Based Learning. International journal of instructon. 1(1). 
Hertiavi, M.A., Langlang, H., \& Khanafiyah, S. 2010. Penerapan Model Pembelajaran Kooperatif Tipe Jigsaw Untuk Peningkatan Kemampuan Pemecahan Masalah Siswa SMP. Jurnal pendidikan Indonesia (ISSN ; 1663-1246), 5357.

Jannah S. N., Doyan A., \& Harjono, A. 2015. Pengaruh Model Pembelajaran Kooperatif Dengan Pendekatan Problem Posing Ditinjau Dari Pengetahuan Awal Terhadap Kemampuan Pemecahan Masalah Fisika Siswa Smk. Jurnal Pendidikan Fisika dan Teknologi (ISSN. 2407-6902) 1(4),259-260.

Misbah. 2016. Identifikasi kemampuan pemecahan masalah mahasiswa pada materi dinamika partikel. Jurnal inovasi dan pemeblajaran fisika (ISSN : 2355-7109).

Odzen, M., \& Gultekin, M. 2008. The Effect Of Brain Based Learning On Accademic Achievement And Ratatio Of Knowledge In Science Course. Elecktronic Journal of Science Education, Vol. 2. No.1.

Puryadi, Rahayu S., \& Sutrio. 2018. Pengaruh Model Pembelajaran Direct Instruction Berbantuan Bahan Ajar Berbasis Kontekstual Terhadap Hasil Belajar Ipa Terapan Siswa Kelas X Smkn 4 Mataram Tahun Ajaran 2015/2016. Jurnal Pendidikan Fisika dan Teknologi, 4(1), 24-25.

Rais, M.2010. Project Based Learning : Inovasi Pembelajaran yang Berorientasi Soft skills. Makasar : Universitas Negeri Makassar.

Rokhmat, J. 2012. Pembelajaran Fisika Berbasis Proses Berpikir Kausalitas Dan Analitik (PBK-BA), Suatu Pembiasaan Berpikir Secara Terbuka. Seminar Nasional IX Pendidikan Biologi FKIP UNS.

Rokhmat, J. 2015. Penerapan Pendekatan Berpikir Kausalitik Ber-
Scaffolding Dalam Meningkatkan KPM Hukum Newton Tentang Gerak. Prosiding Seminar Nasional Fisika.

Sahidu, H., Gunawan, Rokhmat J., \& Rahayu S. 2018. Pengembangan Perangkat Pembelajaran Fisika Berorientasi Pada Kreativitas Calon Guru. Jurnal Pendidikan Fisika dan Teknologi, 4(1).

Santrock, J., W. 2007. Psiko logi Pendidikan Edisi Kedua. Jakarta : Prenada Media.

Sawitri, I., Suparmi., \& Aminah, N., S. 2017. Pembelajaran Fisika Berbasis Problem Based Learning (PBL) Menggunakan Metode Eksperimen Dan Demonstrasi Ditinjai Dari Kemampuan Berpikir Kritis Terhadap Hasil Belajar Dan Keterampilan Metakognitif. Jurnal Inkuri Magister Pendidikan Sains FKIP Universitas Sebelas Maret, 5(2),76-86.

Siregar, S. 2013. Metode Penelitian Kuantitatif Prhitungan Manual Dan SPSS. Jakarta : Prenadamedia Group.

Sugiyarti, H., Sunaro, W., \& Amirah, N.S. 2015. Pendekatan Fisika Dengan Pendekatan Saintifik Menggunakan Metode Proyek Dan Eksperimen Ditinjau Dari Kreativitas Dan Kemampuan Berpikir Kritis Siswa. Jurnal Inkuiri Magister Pendidikan Sains FKIP Universitas Sebelas Maret, 4(4), 34-42.

Sutrio, Gunawan, Harjono A., \& Sahidu H. 2018. Pengembangan Bahan Ajar Fisika Eksperimen Berbasis Proyek Untuk Meningkatkan Keterampilan Berpikir Kritis Calon Guru Fisika. Jurnal Pendidikan Fisika dan Teknologi, 4(1), 131-140.

Trianto. 2013. Mendesain Model Pembelajaran Inovatif, Progresif Dan Kontekstual. Jakarta: Kencana.

Ulya, H. 2015. Hubungan Gaya Kognitif Dengan Kemampuan Pemecahan 
Masalah Matematika Siswa. Jurnal konseling Gusjigang, 1(2).

Wulandari, M. L., Sutrio, \& Rahayu, S. 2017. Pengaruh Model Pembelajaran Conceptual Understanding Procedures (Cups) Terhadap Hasil Belajar Fisika Siswa Kelas Xi Sma Negeri 5 Mataram Tahun Ajaran 2015/2016. Jurnal Pendidikan Fisika dan Teknologi, 3(2), 188-196.

Yeritia, S., Wahyudi., \& Rahayu, S. 2017. Pengaruh Model Pembelajaran Inkuiri Terbimbing Terhadap Penguasaan Konsep dan Kemampuan Berpikir Kritis Fisika Peserta Didik Kelas X SMAN 1 Kuripan Tahun Ajaran 2017/2018. Jurnal Pendidikan Fisika dan Teknologi, 3(3),181-187. 